\title{
COMUNICAÇÃO
}

\section{DOIS CASOS DE ASPERGILOMA PARANASAL POR ASPERGILLUS NIGER}

\author{
Maria Vanda Catão Arnaud, Mário A.P. Moraes e Paulo Nóbrega
}

\begin{abstract}
Aspergiloma intracavitário, aspergilose intracavitária, aspergilose colonizante e colonização aspergilar intracavitária são expressões usadas para designar uma condição em que fungos do gênero Aspergillus se desenvolvem no interior de cavidades do organismo, preexistentes ou não, formando massas micelianas - as bolas fúngicas ou aspergilomas. Constituem essas bolas verdadeiras colônias do fungo, com hifas densamente entrelaçadas - crescendo em saprofitismo -, sem invadir os tecidos; conidióforos e conídios, característicos da espécie, são muitas vezes também produzidos, desde que exista um espaço com ar ao redor da massa fúngica.

$\mathrm{O}$ aspergiloma é mais freqüente nos pulmões, onde os fungos se desenvolvem em escavações devido a várias doenças cavitárias. Bolas fúngicas são assim encontradas em cavernas tuberculosas antigas, abscessos pulmonares crônicos, lesões cicatrizadas e escavadas da sarcoidose, bronquiectasias etc. Podem elas se formar ainda, embora raramente, em outras partes do corpo, sendo comum então o envolvimento dos seios paranasais. Nos dois casos de aspergiloma paranasal, a seguir descritos, ambos diagnosticados no Estado do Pará, a espécie causadora era Aspergillus niger, identificada pelo aspecto das cabeças do fungo existente nos cortes histológicos.
\end{abstract}

\section{Descrição dos casos}

Caso 1: I.B.R., sexo feminino, 67 anos, branca, procedente de Cametá, PA. Em abril de 1990, foi ela submetida à polipectomia nasal e sinusectomia maxilar esquerda, devido à sinusite crônica. Durante o ato operatório, notou-se que o seio maxilar estava cheio de material consistente e fétido, de aspecto não neoplásico, facilmente destacável. Reduzido a fragmentos, para facilitar sua retirada, serviu esse material para estudo histológico.

Caso 2: O.M.S., sexo feminino, 24 anos, branca, procedente de Icoaraci, Belém, PA. Referiu que, em novembro de 1991, após tratamento dentário

Hospital Adventista de Belém, Belém-Pará, Universidade de Brasilia, Brasilia, DF.

Endereço para correspondência: Prof. Mário A.P. Moraes. Instituto Evandro Chagas, Caixa Postal 1128, 66017-970 Belém, PA.

Recebido para publicação em 08/11/93. (endodontia), feito cinco meses antes, passou a ter dor na face e secreção nasal espessa. Uma radiografia dos seios paranasais mostrou velamento do seio maxilar esquerdo, com imagem de densidade metálica projetando-se para dentro da cavidade. Ao ser realizada a sinusectomia, observou-se, no interior do antro, secreção espessa, que foi removida, junto com a mucosa do seio e o fragmento metálico.

Nos cortes histológicos do material obtido dos dois casos viam-se, microscopicamente, aglomerados de hifas, seccionadas transversal e longitudinalmente, bem como secções de vários conidióforos, que foram identificados como de Aspergillus niger, por sua arquitetura e cor dos conídios. Exibiam eles uma vesícula globosa, com a superfície recoberta, em toda sua extensão, por duas séries de fiálides, sendo as primárias mais longas do que as secundárias; as fiálides secundárias davam origem aos conídios, de cor preta.

Com referência ao caso 2 , assinala-se não ser esta a primeira vez que um aspergiloma paranasal é encontrado, no Brasil, com a introdução de corpo estranho metálico no antro maxilar ${ }^{1}$.

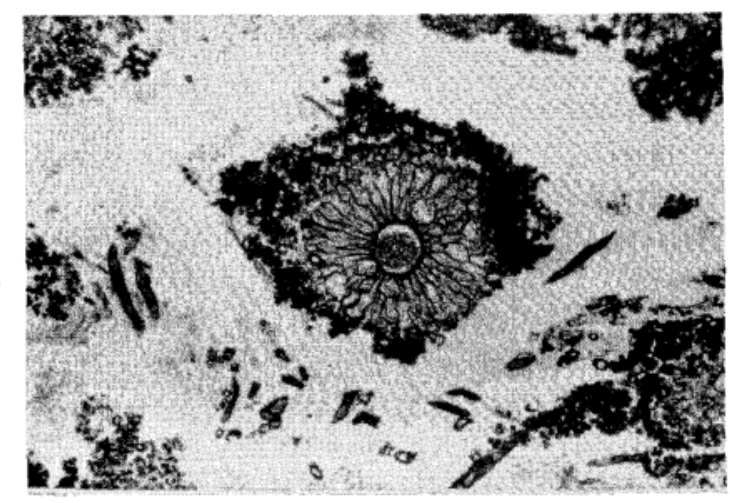

Figura 1-A disposição bisseriada das fiálides, a diferença de tamanho entrefiálides primárias e secundárias, e a cor preta dos conídios permitiram identificar o fungo nos cortes como Aspergillus niger.

\section{REFERÊNCIA BIBLIOGRÁFICA}

1. Saffer M, Severo LC, Nunes MN. Aspergilose nasal com imagem radiológica de corpo estranho metálico. Revista Brasileira de Otorrinolaringologia 52:3234, 1986. 